\title{
HUBUNGAN ANTARA MOTIVASI BELAJAR DAN HASIL BELAJAR BAHASA ARAB MAHASISWA FAKULTAS TARBIYAH DAN KEGURUAN UIN ALAUDDIN MAKASSAR
}

\author{
Syahruddin \\ Fakultas Tarbiyah dan Keguruan UIN Alauddin Makassar \\ Kampus II: Jalan Sultan Alauddin Nomor 36 Samata- Gowa \\ Email: usman.syahruddin@yahoo.co.id
}

\begin{abstract}
Abstrak:
Penelitian ini membahas tentang hubungan antara motivasi belajar dan hasil belajar bahasa Arab mahasiswa jurusan Pendidikan Bahasa Arab pada Fakultas Tarbiyah dan Keguruan UIN Alauddin Makassar. Penelitian ini bertujuan untuk memperoleh gambaran tentang tingkat motivasi belajar bahasa Arab dan hasil belajar bahasa Arab serta hubungan antara motivasi belajar dan hasil belajar bahasa Arab mahasiswa jurusan Pendidikan Bahasa Arab pada Fakultas Tarbiyah dan Keguruan UIN Alauddin Makassar. Lokasi penelitian Fakultas Tarbiyah dan Keguruan UIN Alauddin Makassar. Jenis penelitian ini termasuk penelitian korelasional, pendekatannya kuantitaif. Populasinya adalah seluruh mahasiswa semester V jurusan Pendidikan Bahasa Arab tahun 2014 yang berjumlah 110 orang, sampel 45 orang. Instrumennya adalah angket dan butir soal. Teknik analisis data yang digunakan adalah statistik deskriptif dan infrensial. Hasil penelitian menunjukkan bahwa (1) hasil belajar bahasa Arab mahasiswa jurusan Pendidikan Bahasa Arab pada Fakultas Tarbiyah dan Keguruan UIN Alauddin Makassar secara umum kategori sedang, (2) motivasi belajar mahasiswa kategori tinggi, dan (3)terdapat hubungan yang signifikan antara motivasi belajar dan hasil belajar bahasa Arab dimana $\mathrm{r}_{\text {hitung }}(0,78)$ lebih besar dari $\mathrm{r}_{\text {tabel }}(0,294)$.
\end{abstract}

\begin{abstract}
:
This research discussed about the relationship between learning motivation and Arabic learning outcomes of the students at the Arabic Education Department, faculty of education and teaching science of UIN Alauddin Makassar. This research aimed at obtaining a description of the level of learning motivation and Arabic learning outcomes as well as the relationship between learning motivation and Arabic learning outcomes of students at the Arabic education. The research location was at the faculty of education and teaching science of UIN Alauddin Makassar. The research type was correlational with quantitative approach. The population was all students of the first semester of arabic education department in academic year 2014 that consists of 110 students, and only 45 students was taken as the sample. The research instruments were a questionnaires and a test. The data analysis technique used was descriptive and infrensial statistics. The results of the research sH0wed that (1) The students' learning outcomes in Arabic in general were in the moderate category, (2) The students' learning motivation in general were in the high category, (3) there was a significant relationship between learning motivation and students' learning outcomes in Arabic because the score of $r_{\text {count }}\left(0,78\right.$ was higher than the $r_{\text {tabel }}(0.294)$.
\end{abstract}

Kata kunci:

Motivasi, Hasil Belajar, dan Bahasa Arab 
UNDANG-UNDANG Republik Indonesia nomor 20 tahun 2003 tentang Sistem Pendidikan Nasional, Bab II Pasal 3 menegaskan bahwa pendidikan berfungsi untuk mengembangkan kemampuan dan membentuk watak serta peradaban bangsa yang bermartabat dalam rangka mencerdaskan kehidupan bangsa, bertujuan untuk berkembangnya potensi peserta didik agar menjadi manusia yang beriman dan bertakwa kepada Tuhan Yang Maha Esa, berakhlak mulia, sehat, berilmu, cakap kreatif, mandiri, dan menjadi warga negara yang demokratis serta bertanggung jawab. Selanjutnya Undang-Undang RI No. 20 Tahun 2003 tersebut dinyatakan bahwa pendidikan adalah usaha sadar dan terencana untuk mewujudkan suasana belajar dan proses pembelajaran agar peserta didik secara aktif mengembangkan potensi dirinya untuk memiliki kekuatan spiritual keagamaan, pengendalian diri, kepribadian, kecerdasan, akhlak mulia, serta keterampilan yang diperlukandirinya, masyarakat, bangsa dan negara.

Berorientasi pada fungsi dan tujuan pendidikan nasional tersebut, maka sekolah sebagai salah satu lembaga pendidikan (formal), mempunyai misi dan tugas yang cukup berat. Selanjutnya, sekolah berperan untuk mencerdaskan kehidupan bangsa, memiliki arti menumbuhkan, memotivasi dan mengembangkan nilai-nilai budaya yang mencakup etika, logika, estetika, dan praktika, sehingga tercipta manusia yang utuh dan berakar pada budaya bangsa. ${ }^{1}$

Motivasi merupakan salah satu faktor yang berpengaruh terhadap keberhasilan peserta didik atau mahasiswa. Seseorang akan mendapat hasil yang diinginkan dalam belajar apabila dalam dirinya terdapat keinginan untuk belajar. Motivasi memiliki peran yang penting bagi mahasiswa dalam mengembangkan aktivitas dan inisiatif, mengarahkan dan memelihara dalam melakukan kegiatan belajar, terkhusus bagi mahasiswa jurusan Pendidikan Bahasa Arab.

Motivasi merupakan salah satu faktor yang diduga memiliki hubungan yang kuat dengan hasil belajar. Mahasiswa yang motivasinya tinggi diduga akan memperoleh hasil belajar yang baik. Pentingnya motivasi belajar mahasiswa terbentuk antara lain agar terjadi perubahan belajar ke arah yang lebih positif. Pandangan ini sesuai dengan pendapat Hawley dalam Prayitno siswa/mahasiswa yang termotivasi dengan baik dalam belajar melakukan kegiatan lebih banyak dan lebih cepat, dibandingkan dengan siswa/mahasiswa yang kurang termotivasi dalam belajar. Prestasi yang diraih akan lebih baik apabila mempunyai motivasi yang tinggi. ${ }^{2}$

Hasil belajar mahasiswa merupakan output dari proses belajar. Dengan demikian, faktor-faktor yang memengaruhi proses belajar juga langsung memengaruhi hasil belajar. Untuk memperoleh hasili belajar yang maksimal dengan hasil yang baik, maka harus benar-benar memperhatikan berbagai faktor yang memengaruhinya. Sehubungan dengan hal tersebut terdapat 2 faktor yang berpengaruh terhadap hasil belajar, yaitu: faktor internal dan faktor eksternal. Faktor internal adalah faktor-faktor yang berasal dari individu itu sendiri yang meliputi faktor jasmaniah (fisiologis) dan faktor psikologis. Yang termasuk faktor jasmaniah (fisiologis) antara lain penglihatan, pendengaran, struktur tubuh dan sebagainya, sedangkan yang termasuk faktor psi- 
kologis meliputi intelektul (taraf intelegensi, kemampuan belajar, dan cara belajar), nonintelektual (motivasi belajar, sikap, perasaan, minat, kondisi psikis, dan kondisi akibat keadaan sosiokultur), dan faktor kondisi fisik. Faktor eksternal, yaitu faktor yang berasal dari luar individu yang meliputi faktor fisik dan faktor lingkungan sosial. Faktor fisik sendiri meliputi rumah, sekolah, peralatan, dan alam, sedangkan faktor lingkungan sosial meliputi keluarga, guru, masyarakat, dan teman.

Menurut Wlodkowsky dalam Sugihartono, motivasi adalah suatu kondisi yang menyebabkan atau menimbulkan perilaku tertentu dan yang memberi arah dan ketahanan pada tingkah laku tersebut. ${ }^{3}$ Motivasi belajar yang tinggi tercermin dari ketekunan yang tidak mudah patah untuk mencapai sukses meskipun menghadapi berbagai rintangan. Demikian pula halnya bila dilihat dalam proses pembelajaran bahasa Arab. Mahasiswa yang memiliki motivasi yang tinggi dalam mempelajari bahasa Arab akan melakukan aktivitas/kegiatan lebih cepat dibandingkan dengan mahasiswa yang kurang termotivasi dalam mempelajari bahasa Arab. Dengan motivasi tinggi yang dimiliki mahasiswa dalam belajar bahasa Arab, maka akan berpengaruh terhadap hasil belajarnya.

Berdasarkan pengamatan sementara, mahasiswa Jurusan Pendidikan Bahasa Arab terlihat kemampuan berkomunikasi dan membaca kitab kuning serta hasil belajar mereka rendah. Dengan dasar ini, peneliti tertarik untuk melihat lebih jauh apakah motivasi mereka belajar ada hungannya dengan hasil belajar bahasa Arab, khususnya mahasiswa jurusan Pendidikan Bahasa Arab Fakultas Tarbiyah dan Keguruan UIN Alauddin Makssar.

\section{KAJIAN TEORI}

\section{Hasil Belajar}

\section{Pengertian Hasil Belajar}

Hasil adalah hasil dari suatu kegiatan yang telah dikerjakan dan diciptakan, baik secara individu maupun secara kelompok. ${ }^{4}$ Selanjutnya Djamarah mengatakan bahwa prestasi adalah apa yang dapat diciptakan, hasil pekerjaan, dan hasil yang menyenangkan hati yang diperoleh dengan jalan keuletan kerja. ${ }^{5}$ Menurut Slameto, belajar adalah suatu proses usaha yang dilakukan seseorang untuk memperoleh suatu perubahan tingkah laku yang baru secara keseluruhan, sebagai hasil pengalamannya sendiri dalam interaksi dengan lingkungannya. ${ }^{6}$ Secara sederhana, pengertian belajar sebagaimana yang dikemukakan oleh pendapat di atas dapat diambil suatu pemahaman tentang hakikat dari aktivitas belajar, yaitu suatu perubahan yang terjadi dalam diri individu.

Berdasarkan uraian di atas, maka dapat dipahami bahwa hasil belajar adalah hasil yang telah dicapai peserta didik setelah mengikuti proses pembelajaran dalam waktu tertentu, baik berupa perubahan tingkah laku dan keterampilan maupun pengetahuan kemudian akan diukur dan dinilai lalu diwujudkan dalam angka atau pernyataan. Abdurahman mengatakan hasil belajar adalah suatu kemampuan yang 
diperoleh anak atau peserta didik setelah melalui kegiatan belajar. ${ }^{7}$ Kegiatan pembelajaran yang baik adalah apabila mampu membangkitkan gairah belajar peserta didik. Gairah belajar peserta didik dapat diukur di antaranya melalui hasil belajar yang diperolehnya setelah mengikuti kegiatan pembelajaran.

\section{Faktor-Faktor yang Memengaruhi Hasil Belajar Mahasiswa}

Untuk mencapai prestasi/hasil belajar mahasiswa sebagaimana yang diharapkan, diperhatikan beberapa faktor yang memengaruhi prestasi/hasil belajar, antara lain faktor yang terdapat dalam diri mahasiswa (faktor intern) dan faktor yang terdiri atas luar mahasiswa (faktor ekstern). Faktor-faktor yang berasal dari dalam diri mahasiswa seperti kecerdesan/intelegensi, bakat, minat, dan motivasi. Sedangkan faktor yang berasal dari luar diri mahasiswa antara lain faktor keluarga, sekolah, dan masyarakat.

Dimyati dan Mudjiono mengatakan hasil belajar merupakan tujuan akhir dilaksanakannya kegiatan pembelajaran di sekolah atau di perguruan tinggi. ${ }^{8}$ Hasil belajar dapat ditingkatkan melalui usaha sadar yang dilakukan secara sistematis mengarah kepada perubahan yang positif yang kemudian disebut dengan proses belajar. Akhir dari proses belajar adalah perolehan suatu hasil belajar peserta didik. Semua hasil belajar yang diperoleh mahsiswa/peserta didik tersebut merupakan hasil dari suatu interaksi tindak belajar dan tindak mengajar. Dari sisi guru/dosen, tindak mengajar diakhiri dengan proses evaluasi hasil belajar, sedangkan dari sisi peserta didik, hasil belajar merupakan puncak proses belajar.

Menurut Sudjana hasil belajar adalah kemampuan yang dimiliki peserta didik setelah menerima pengalaman belajar. ${ }^{9}$ Sehubungan dengan pendapat itu, maka Wahidmurni, dkk. menjelaskan bahwa sesorang dapat dikatakan telah berhasil dalam belajar jika ia mampu menunjukkan adanya perubahan dalam dirinya. ${ }^{10}$ Perubahanperubahan tersebut di antaranya dari segi kemampuan berpikir, keterampilan, atau sikapnya terhadap suatu objek. Jika dikaji lebih mendalam, hasil belajar dapat tertuang dalam taksonomi Bloom yang dikelompokkan dalam tiga ranah (domain), yaitu: domain kognitif atau kemampuan berpikir, domain afektif atau sikap, dan domain psikomotor atau keterampilan.

Berdasarkan pernyataan di atas, maka dapat ditarik suatu konkulusi bahwa hasil belajar tampak dari terjadinya perubahan tingkah laku pada diri peserta didik yang dapat diamati dan diukur melalui perubahan sikap dan keterampilan. Perubahan tersebut dapat diartikan terjadinya peningkatan dan pengembangan yang lebih baik dibandingkan dengan sebelumnya.

\section{Motivasi Belajar}

\section{Pengertian Motivasi}

Nasution mengatakan bahwa motivasi adalah "Segala daya yang mendorong seseorang untuk melakukan sesuatu."11 Sedangkan menurut Wlodkowsky dalam Sugihartono dkk., bahwa motivasi adalah suatu kondisi yang menyebabkan atau 
menimbulkan perilaku tertentu dan yang memberi arah dan ketahanan pada tingkah laku tersebut. ${ }^{12}$ Selanjutnya, Samosir mengungkapkan pengertian motivasi menurut pakar psikologi yaitu motivasi sebagai proses internal yang mengaktifkan, menuntun, dan mempertahankan perilaku dari waktu ke waktu. ${ }^{13}$ Jadi, dalam bahasa sederhananya motivasi adalah sesuatu yang medorong sesorang melangkah, membuat, dan menentukan sesuatu yang ingin ia capai. Dilihat dari perspektif Islam, niat sering disamakan denga motivasi. Niat merupakan dorongan hati untuk melakukan suatu tidakan untuk mencapai tujuan, baik yang mendatangkan manfaat maupun yang mendatngkan mudarat. Gambaran ini dapat dilihat dalam salah satu hadis Rasulullah saw. yang diriwayatkan oleh al-Buhkari dan Muslim dari Umar bin al-Khaththab ra. sebagai berikut:

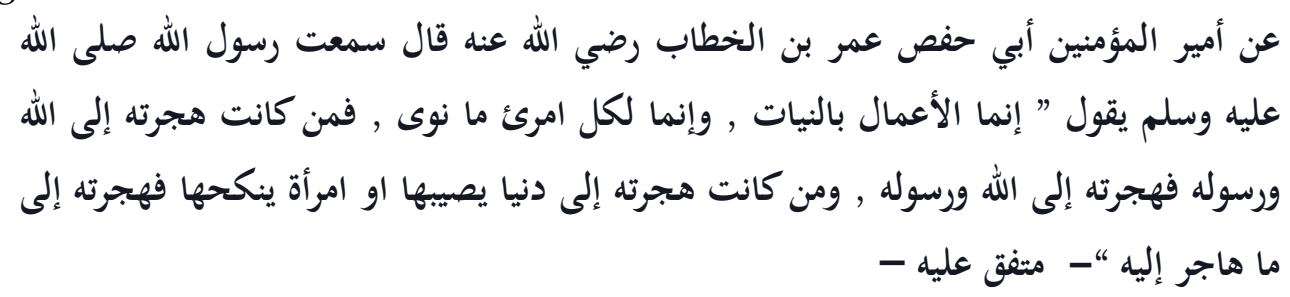

Dari Amirul Mukminin Abu Hafsh, Umar bin Al-Khathab radhiyallahu 'anhu, ia berkata: "Aku mendengar Rasulullah shallallahu 'alaihi wa sallam bersabda: "Segala amal itu tergantung niatnya, dan setiap orang hanya mendapatkan sesuai niatnya. Maka barang siapa yang hijrahnya kepada Allah dan Rasul-Nya, maka hijrahnya itu kepada Allah dan Rasul-Nya. Barang siapa yang hijrahnya itu Karena kesenangan dunia atau karena seorang wanita yang akan dikawininya, maka hijrahnya itu kepada apa yang ditujunya".

Hadis tersebut jika dicermati secara mendalam dapat diperoleh petunjuk bahwa orang melakukan sesuatu tindakan didorong atau dimotivasi oleh sesuatu yang ingin diraih. Ada orang melakukan suatu tindakan atau perbuatan karena dorongan materi atau dunia, dan ada juga orang melakukan tindakan atau perbuatan karena dorongan ukhrawi atau pahala. Pada hadis ini terlihat ada motivasi yang mendorong orang hijrah yaitu hijrah karena Allah dan hijrah karena wanita yang ingin dinikahi. Berdasarkan hadis tersebut, niat dapat disamakan dengan motivasi. Motivasi itu besar pengaruhnya terhadap aktivitas seseorang. Orang berhasil meraih sesuatu yang dinginkan sangat terkait dengan motivasinya. Jika hal tersebut dikaitkan dengan belajar, dapat dipahami bahwa peserta didik yang memiliki motivasi belajar yang tinggi, ia melakukan berbagai aktivitas belajar untuk meraih apa yang dicita-citakan.

Moslow membagi kebutuhan menjadi lima tingkatan yakni: (a) kebutuhan fisiologis, (b) kebutuhan akan rasa aman, (c) kebutuhan social/rasa cinta, (d) kebutuhan akan penghargaan diri, dan (e) kebutuhan aktualisasi. ${ }^{14}$

Kebutuhan fisiologis juga disebut kebutuhan jasmaniah (biologi), yaitu kebutuhan manusia yang erat hubungannya dengan proses kehidupan jasmaniah. Kebutuhan ini sifatnya sangat primer dan universal. Artinya mutlak harus dipenuhi oleh siapa saja, kapan saja, dan di mana saja. Jika kebutuhan ini tidak terpenuhi, kelangsungan hidup manusia akan terancam dan dapat membawa kematian. ${ }^{15}$ 
Kebutuhan akan rasa aman adalah kebutuhan untuk senantiasa berada dalam situasi nyaman dan terbebas dari rasa takut dan ancaman. Dengan terpenuhinya kebutuhan ini, orang akan merasa berada dalam situasi yang tentram bebas dari ketegangan. Banyak orang yang terdorong dan betah dalam situasi tertentu seperti pekerjaan, pendidikan, dan dalam keluarga, karena dapat menimbulkan rasa aman dan tentram. Sebaliknya, banyak pula orang yang merasa gelisah dalam melaksanakan tugasnya karena di dalamnya tidak terdapat rasa aman. ${ }^{16}$

Kebutuhan sosial seperti dicinta atau mencinta. Apabila kebutuhan fisiologis dan keselamatan cukup terpenuhi, akan muncul kebutuhan akan cinta, rasa kasih, dan rasa memiliki. Sudah merupakan kodratnya bahwa manusia akan tergantung kepada manusia lain. Maka kini orang akan sangat merasakan ketiadaan kawan, kekasih, isteri, atau anak. Ia haus akan hubungan yang penuh kasih dengan orangorang pada umumnya, yakni haus akan suatu tempat dalam kelompok atau keluarganya sehingga ia akan berikhtiar lebih keras lagi untuk mencapai tujuan ini. Ia akan berupaya mendapatkan tempat seperti itu lebih daripada yang lainnya di dunia ini, dan mungkin dengan melupakan bahwa ketika ia lapar, ia pernah mencemoohkan cinta sebagai sesuatu yang tidak nyata, tidak perlu, atau tidak penting. Sekarang ia akan sangat merasakan perihnya rasa kesepian itu, pengucilan sosial, penolakan, tiadanya keramahan, dan keadaan yang tak menentu. ${ }^{17}$

Kebutuhan akan penghargaan diri. Kebutuhan jenis ini dapat diklasifikasikan dalam dua perangkat tambahan. Pertama, keinginan akan kekuatan, prestasi, kecukupan, keunggulan, kemampuan, dan kepercayaan pada diri sendiri dalam menghadapi dunia serta kemerdekaan dan kebebasan. Kedua, manusia memiliki apa yang disebut hasrat akan nama baik atau gengsi, prestise (yang dirumuskan sebagai pengH0rmatan dan penghargaan dari orang lain), staus, ketenaran dan kemuliaan, dominasi, pengakuan, perhatian, arti yang penting, dan martabat atau apresiasi. ${ }^{18}$

Kebutuhan akan aktualisasi diri. Meskipun semua kebutuhan ini telah dipenuhi, orang masih sering merasa bahwa perasaan tidak puas dan kegelisahan baru akan segera berkembang, kecuali apabila orang itu melakukan apa yang secara individual sesuai dirinya. Maslow menggambarkan aktualisasi diri sebagai orang perlu untuk menjadi dan melakukan apa yang orang itu "lahir untuk dilakukan." "Seorang musisi harus bermusik, seniman harus melukis, dan penyair harus menulis." Kebutuhan ini membuat diri mereka merasa dalam tanda-tanda kegelisahan. Orang itu merasa di tepi, tegang, kurang sesuatu, singkatnya, gelisah. Jika seseorang lapar, tidak aman, tidak dicintai atau diterima, atau kurang harga diri, sangat mudah untuk mengetahui orang itu gelisah. Hal ini tidak selalu jelas apa yang seseorang ingini ketika ada kebutuhan untuk aktualisasi diri. ${ }^{19}$

Aktualisasi diri adalah kemampuan seseorang mengembangkan potensi yang dimilikinya. Aktualisasi diri dicirikan oleh penerimaan terhadap diri sendiri dan orang-orang lain, spontanitas, keterbukaan, kreativitas, ekspresi diri, hubungan yang relatif mendalam dengan orang lain, tetapi demokratis, kreativitas, humor dan kebebasan. ${ }^{20}$ 
Dengan terpenuhinya lima kebutuhan tersebut, orang akan merasa berada dalam situasi yang tenteram, bebas dari ketegangan. Banyak orang yang terdorong dan betah dalam situasi tertentu seperti pekerjaan, pendidikan, keluarga, karena dapat menimbulkan rasa aman dan tenteram. Sebaliknya, banyak pula orang yang merasa gelisah dalam melaksanakan tugasnya karena di dalamnya tidak terdapat rasa aman.

Dorongan atau motivasi merupakan kekuatan mental untuk melakukan kegiatan dalam rangka memenuhi harapan. Sedangkan tujuan adalah hal yang ingin dicapai oleh seorang individu.

\section{Macam-macam Motivasi}

Woodwort dan Marquis dalam Purwanto mengemukakan bahwa motif itu ada tiga golongan: 1) Kebutuhan-kebutuhan organis yakni, motif-motif yang berhubungan dengan kebutuhan-kebutuhan bagian dalam dari tubuh seperti lapar, haus, kebutuhan bergerak, beristirahat atau tidur, dan sebagainya. 2) Motif-motif yang timbul sekonyong-konyong (emergency motives). Inilah motif yang timbul bukan karena kemauan individu, melainkan karena ada rangsangan dari luar, seperti: motif melarikan diri dari bahaya dan motif berusaha mengatasi suatu rintangan. 3) Motif obyektif, yaitu motif yang diarahkan atau ditujukan ke suatu objek atau tujuan tertentu di sekitar manusia, timbul karena adanya dorongan dari dalam diri manusia. ${ }^{21}$ Arden $\mathrm{N}$. Frandsen dalam Sardiman A.M., mengemukakan bahwa jenis motivasi dilihat dari dasar pembentukannya, yaitu: motif bawaan, (motive psycHOlogical drives) dan motif yang dipelajari (affiliative needs), misalnya: dorongan untuk belajar suatu cabang ilmu pengetahuan dan sebagainya. Jadi, motivasi itu dapat dirangkai oleh faktor dari luar tetapi motivasi tumbuh di dalam diri seseorang. ${ }^{22}$

Menurut Sardiman, ada tiga fungsi motivasi: (a) Mendorong manusia untuk berbuat, ia menjadi penggerak atau motor yang melepaskan. Motivasi dalam hal ini merupakan motor penggerak dari setiap kegiatan yang akan dikerjakan; (b) Menentukan arah perbuatan, yakni tujuan yang hendak dicapai. Dengan demikian, motivasi dapat memberikan arah dan kegiatan yang harus dikerjakan sesuai dengan rumusan tujuannya; dan (c) Menyeleksi perbuatan, yakni menentukan perbuatanperbuatan apa yang harus dikerjakan dan yang serasi, guna mencapai tujuan dengan menyisihkan perbuatan-perbuatan yang tidak bermanfaat bagi tujuan tersebut. Seorang peserta didik yang akan menghadapi ujian dengan harapan dapat lulus tentu akan melakukan kegiatan belajar dan tidak akan menghabiskan waktunya untuk bermain kartu atau membaca komik sebab tidak sesua dengan tujuan. ${ }^{23}$

Sementara Hamalik mengemukakan tiga fungsi motivasi yang meliputi: (a) Mendorong timbulnya kelakuan atas sesuatu perbuatan. Tanpa motivasi maka tidak akan timbul sesuatu perbuatan seperti belajar; (b) Motivasi berfungsi sebagai pengarah. Artinya mengarahkan perbuatan ke pencapaian tujuan yang diinginkan; dan (c) Motivasi berfungsi sebagai penggerak. Ia berfungsi sebagai mesin bagi mobil. Besar kecilnya motivasi akan menentukan cepat atau lambatnya suatu pekerjaan. ${ }^{24}$ 
Berdasarkan uraian yang telah dipaparkan di atas, dapat diambil kesimpulan bahwa yang perlu dilakukan dalam meningkatkan motivasi belajar mahasiswa dengan penerapan Hierarki Maslow sebagai berikut: (1) Pemenuhan kebutuhan dasar mahasiswa harus didahulukan, karena kebutuhan ini sangat mendesak dan hendaknya para pendidik memberikan kesempatan atau bantuan kepada mahasiswa untuk memenuhinya. (2) Kebutuhan akan keamanan di kelas menjadi tanggung jawab para pendidik. Tugas para pendidik memberikan peraturan dan jaminan atas keselamatan mahasiswa serta kenyamanan kelas. (3) Terkait dengan kebutuhan sosial mahasiswa, para pendidik hendaknya memberikan perhatian supaya mahasiswa/peserta didik mampu berinteraksi dengan baik dan mempunyai rasa saling memiliki terhadap teman-temannya serta lingkungan sekelilingnya. (4) Prestasi peserta didik/mahasiswa sekecil apapun perlu diberikan apresiasi. Memberikan penghargaan kepada peserta didik/mahasiswa mampu memotivasi mereka untuk meningkatkan prestasinya. (5) Ketika peserta didik/mahasiswa sudah di tahap aktualisasi diri, pendidik hanya tinggal memberikan fasilitas yang diperlukan untuk mengembangkan dirinya lebih jauh.

\section{Kerangka Pikir}

Kerangka pikir murupakan alur pikir untuk menghubungakan teori-teori yang menjadi dasar setiap variabel atau yang menjadi obyek penelitian. Dalam penelitian ini, terdapat dua variabel yaitu variabel X (motivasi) dan Y (hasil belajar bahasa Arab).

Prestasi belajar adalah hasil yang telah dicapai mahasiswa setelah mengikuti proses pembelajaran dalam waktu tertentu, baik berupa perubahan tingkah laku, keterampilan, maupun pengetahuan kemudian diukur dan dinilai dalam angka/hasil atau pernyataan. Berdasarkan pernyataan tersebut dipahami bahwa motivasi belajar dapat berdampak terhadap aktivitas belajar dan akhirnya dapat berkorelasi pada hasil belajar.

\section{METODE PENELITIAN}

\section{Jenis Penelitian}

Jenis penelitian ini termasuk penelitian korelasional jika dilihat dari tingkat eksplanasinya. Dikatakan penelitian korelatif karena dalam penelitian ini yang ingin diperoleh adalah korelasi antara variabel $X$ yaitu motivasi dan Yang yaitu hasil belajar bahasa Arab. Penelitian korelatif adalah penelitian yang dilakukan untuk menghubungkan antara variabel yang satu dengan yang lain..$^{25}$

\section{Lokasi dan Pendekatan Penelitian}

Penelitian ini berlokasi di Fakultas Tarbiyah dan Keguruan UIN Alauddin Makassar pada Jurusan Pendidikan Bahasa Arab. Pendekatan yang digunakan dalam penelitian ini adalah pendekatan kuantitatif. 


\section{Populasi dan Sampel}

Populasi dalam penelitian ini adalah seluruh peserta didik/mahasiswa semester V tahun 2014 pada jurusan Pandidikan Bahasa Arab di Fakultas Tarbiyah dan Keguruan UIN Alauddin Makassar yang berjumlah 110 orang.

Memperhatikan jumlah populasi tersebut 110 responden, maka jumlah sampel yang diambil 45 orang dari seluruh populasi. Teknik pengambilannya dilakukan secara acak atau random

\section{Instrumen Penelitian}

Koesioner, digunakan untuk memperoleh data tentang motivasi belajar bahasa Arab responden yang terdiri atas 20 item. Setiap itemnya dilengkapi dengan empat pilihan jawaban, yaitu: selalu, kadang-kadang, jarang, dan tidak pernah. Skor untuk pilihan selalu $=4$, kadang-kadang $=3$, jarang $=2$, dan tidak pernah $=1$. Jumlah yang tertinggi yang dapat diperoleh responden adalah 80, sedangkan jumlah yang terendah yang dapat diperoleh responden adalah 20. Instrumen penelitian ini telah divalidasi sebelum digunakan. Data dianalisis dengan menggunakan program Statistical Product and Service Solution (SPSS).

Tes, digunakan untuk mengumpulkan data tentang hasil belajar responden dalam bentuk tes pilihan ganda. Jumlah item soalnya 20, setiap jawaban yang benar diberi skor 1 dan jawaban yang salah diberi skor 0 . Jumlah yang tertinggi yang dapat diperoleh responden adalah 20, sedangkan jumlah yang terendah yang mungkin dapat diperoleh responden adalah 0 . Instrumen penelitian ini telah divalidasi sebelum digunakan.

Format Dokumentasi, digunakan untuk mencatat jumlah mahasiswa yang aktif mengikuti perkulihan pada jurusan Pendidikan Bahasa Arab. Penyusunan instrumen berpedoman pada indikator pada setiap variabel.

\section{Teknik Analisis Data}

Data yang terkumpul, dianalisis dengan menggunakan analisis statistik deskriptif dan inferensial untuk menguji hipotesis. Analisis statistik deskriptif meliputi nilai maximun, nilai minimun, mean atau rata-rata, median, modus, prsentase, standar deviasi, dan diagram. Data hasil belajar bahasa Arab responden yang terkumpul dikategorikan menjadi lima kategori, yaitu sangat tinggi, tinggi, sedang, rendah, dan sangat rendah.

Untuk mengetahui ada tidaknya hubungan antara motivasi belajar dan hasil belajar bahasa Arab dianalisis dengan teknik korelasi product moment. Penggunaan rumus tersebut dimaksudkan untuk mencari hubungan dan menguji hipotesis dua variabel dengan nilai $r_{h i t u n g}$ dikonsultasikan ke nilai $r_{\text {tabel }}$. Jika $r_{h i t u n g}$ lebih tinggi dari $\mathrm{r}_{\text {tabel}}$, hipotesis alternatif diterima atau $\mathrm{H}_{1}$ diterima dan $\mathrm{H}_{0}$ ditolak. Untuk mengetahui keeratan hubungan antara variabel $\mathrm{X}$ dan $\mathrm{Y}$. Nilai $\mathrm{r}$ dikonsultasikan ke pedoman interpretasi nilai $\mathrm{r}$ sebagai berikut: 
Tabel 2. Pedoman untuk Menginterpretasikan Koefisien Korelasi (r) ${ }^{26}$

\begin{tabular}{|c|c|}
\hline Interval & Koefisien Tingkat Hubungan \\
\hline $0,00-0,199$ & Sangat rendah \\
\hline $0.20-0,399$ & Rendah \\
\hline $0,40-0,599$ & Sedang \\
\hline $0,60-0,799$ & Kuat \\
\hline $0,80-1,000$ & Sangat Kuat \\
\hline
\end{tabular}

Untuk memudahkan pengolahan data dalam penelitian ini penulis menggunakan fasilitas program komputer yaitu SPSS 16 for windows.

\section{HASIL PENELITIAN}

\section{Hasil Belajar Bahasa Arab Mahasiswa}

Data hasil belajar bahasa Arab responden yang terkumpul dikategorikan menjadi empat kategori, yaitu sangat tinggi, tinggi, sedang, rendah, dan sangat rendah. Penentuan kategori tersebut didasarkan pada nilai total yang dikonversi ke nilai standar baku. Hasil penelitian menunjukan bahwa perolehan nilai maximun 18, nilai minimun 4, mean atau rata-rata sebesar 1,18, median 11, modus sebesar 8 , standar deviasi 3,595. Distribusi frekuensi dan presentase hasil belajar bahasa Arab responden dapat dilihat pada tabel di bawah ini.

\section{Tabel 3. Distribusi Frekuensi dan Presentase Hasil Belajar Bahasa Arab Responden}

\begin{tabular}{|c|c|l|c|c|}
\hline No & Nilai & Kategori pengetahuan & Frekuensi $(\mathrm{F})$ & Prsentase $(\%)$ \\
\hline 1 & $17-20$ & Sangat tinggi & 3 & 6.66 \\
\hline 2 & $13-16$ & Tinggi & 14 & 31.11 \\
\hline 3 & $9-12$ & Sedang & 14 & 31.11 \\
\hline 4 & $5-8$ & Rendah & 13 & 28,9 \\
\hline 5 & $0-4$ & Sangat rendah & 1 & 2.22 \\
\hline \multicolumn{2}{|r}{} & Jumlah & 45 & 100.00 \\
\hline
\end{tabular}

Sumber data : Survei 2014

Berdasarkan tabel tersebut tergambar bahwa dari 45 responden/mahasiswa 3 orang memperoleh hasil belajar berada pada peringkat sangat tinggi atau 6,66 pesen, 14 responden/mahasiswa atau 31,11 persen memperoleh hasil belajar bahasa Arab berada pada kategori tinggi, 14 responden/mahasiswa atau 31,11 persen memperoleh hasil belajar bahasa Arab berada pada kategori sedang, 13 responden/mahasiswa atau 28,9 persen memperoleh hasil belajar bahasa Arab berada pada kategori rendah, dan 1 responden/mahasiswa atau 2,22 persen berada pada kategori sangat rendah.

Berdasarkan persentase di atas maka dapat ditarik kesimpulan bahwa hasil belajar bahasa Arab responden/mahasiswa jurusan Pendidikan Bahasa Arab pada Fak. Tarbiyah dan Keguruan UIN Alauddin Makassar pada umumnya berada pada kategori sedang cenderung tinggi sebagaimana terlihat pada diagram di berikut ini: 


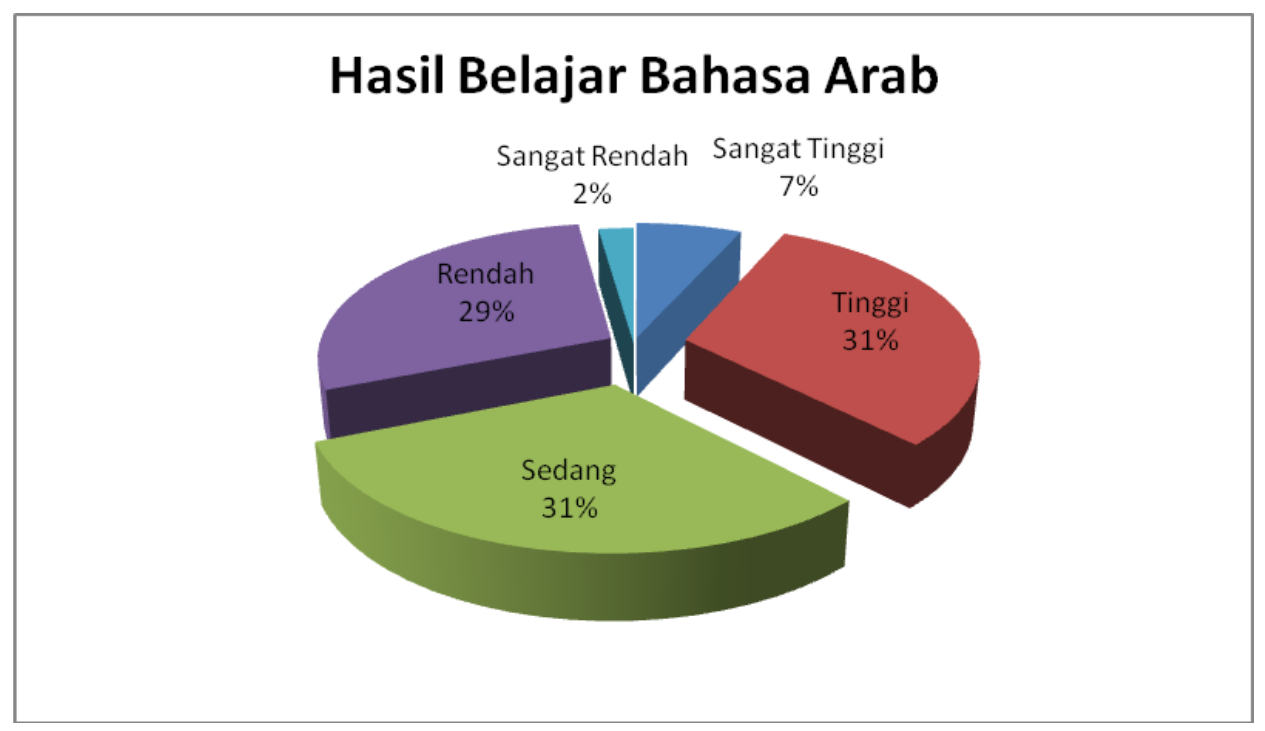

Gambar 1. Diagram Hasil Belajar Bahasa Arab 2014

Motivasi Belajar Bahasa Arab Responden/Mahasiswa

Data terkumpul dikategorikan menjadi empat kategori, yaitu selalu (senantiasa melakukan atau selamanya melakukan), kadang (tidak selamanya melakukan), jarang (sekali sampai tiga kali dilakukan), dan tidak pernah. Pengategorian tersebut melalui distribusi frekuensi dan persentase sebagaimana dituangkan dalam rekapitulasi motivasi belajar bahasa Arab reponden/mahasiswa dalam bentuk tabel 4 .

Tabel 4. Distribusi Frekuensi Rekapitulasi motivasi belajar bahasa Arab mahasiswa jurusan Pendidikan Bahasa Arab semester V 2014 Fakultas Tarbiyah dan Keguruan UIN Alauddin Makassar

\begin{tabular}{|c|c|c|c|c|c|c|c|c|c|c|}
\hline \multirow{3}{*}{ No. } & \multirow{3}{*}{$\begin{array}{c}\text { Pernya } \\
\text { taan }\end{array}$} & \multicolumn{8}{|c|}{ Jawaban } & \multirow{3}{*}{$\begin{array}{c}\text { Jumlah } \\
\%\end{array}$} \\
\hline & & \multicolumn{2}{|c|}{ Selalu } & \multicolumn{2}{|c|}{ Kadang } & \multicolumn{2}{|c|}{ Jarang } & \multicolumn{2}{|c|}{ Tidak Pernah } & \\
\hline & & $\mathrm{F}$ & $\%$ & $\mathrm{~F}$ & $\%$ & $\mathrm{~F}$ & $\%$ & $\mathrm{~F}$ & $\%$ & \\
\hline 1 & A & 34 & 75,6 & 7 & 15,6 & 3 & 6,7 & 1 & 2,2 & 100 \\
\hline 2 & B & 18 & 40 & 22 & 48.9 & 4 & 8.9 & 1 & 2.2 & 100 \\
\hline 3 & C & 13 & 28.9 & 27 & 60 & 5 & 11.1 & 0 & 0 & 100 \\
\hline 4 & $\mathrm{D}$ & 37 & 82.2 & 5 & 11.1 & 2 & 4.4 & 1 & 2.2 & 100 \\
\hline 5 & $\mathrm{E}$ & 17 & 37.8 & 13 & 28.9 & 9 & 20 & 6 & 13.3 & 100 \\
\hline 6 & $\mathrm{~F}$ & 5 & 11.1 & 36 & 80 & 3 & 6.7 & 1 & 2.2 & 100 \\
\hline 7 & $G$ & 18 & 40 & 22 & 48.9 & 4 & 8.9 & 1 & 2.2 & 100 \\
\hline 8 & $\mathrm{H}$ & 14 & 31.1 & 27 & 60.0 & 2 & 4.4 & 2 & 4.4 & 100 \\
\hline 9 & $\mathrm{I}$ & 20 & 44.4 & 19 & 42.2 & 5 & 11.1 & 1 & 2.2 & 100 \\
\hline 10 & $\mathrm{~J}$ & 32 & 71.1 & 10 & 22.2 & 2 & 4.4 & 1 & 2.2 & 100 \\
\hline 11 & $\mathrm{~K}$ & 30 & 66.7 & 12 & 26.7 & 3 & 6.7 & 0 & 0 & 100 \\
\hline 12 & $\mathrm{~L}$ & 19 & 42.2 & 20 & 44.4 & 5 & 11.1 & 1 & 2.2 & 100 \\
\hline 13 & $\mathrm{M}$ & 27 & 60.0 & 14 & 31.1 & 3 & 6.7 & 1 & 2.2 & 100 \\
\hline 14 & $\mathrm{~N}$ & 17 & 37.8 & 21 & 46.7 & 5 & 11.1 & 2 & 4.4 & 100 \\
\hline 15 & $\mathrm{O}$ & 9 & 20.0 & 11 & 24.4 & 10 & 22.2 & 15 & 33.3 & 100 \\
\hline 16 & $\mathrm{P}$ & 5 & 11.1 & 15 & 33.3 & 12 & 26.7 & 13 & 28.9 & 100 \\
\hline
\end{tabular}




\begin{tabular}{|c|c|c|c|c|c|c|c|c|c|c|}
\hline \multirow{2}{*}{ No. } & \multirow{2}{*}{$\begin{array}{c}\text { Pernya } \\
\text { taan }\end{array}$} & \multicolumn{8}{|c|}{ Jawaban } & Jumlah \\
\hline & & \multicolumn{2}{|c|}{ Selalu } & \multicolumn{2}{|c|}{ Kadang } & \multicolumn{2}{|c|}{ Jarang } & \multicolumn{2}{|c|}{ Tidak Pernah } & \\
\hline 17 & Q & 6 & 13.3 & 21 & 46.7 & 13 & 28.9 & 5 & 11.1 & 100 \\
\hline 18 & $\mathrm{R}$ & 29 & 64.4 & 9 & 20.0 & 3 & 6.7 & 4 & 8.9 & 100 \\
\hline 19 & $\mathrm{~S}$ & 15 & 33.3 & 23 & 51.1 & 3 & 6.7 & 4 & 8.9 & 100 \\
\hline 20 & $\mathrm{~T}$ & 14 & 31.1 & 23 & 51.1 & 4 & 8.9 & 4 & 8.9 & 100 \\
\hline \multicolumn{2}{|c|}{ Jumlah } & 379.0 & 842.1 & 357.0 & 793.3 & 100.0 & 222.3 & 64.0 & 141.9 & 2000.0 \\
\hline \multicolumn{2}{|c|}{ Rata-rata } & 18.95 & 42.10 & 17.85 & 39.66 & 5.00 & 11.11 & 3.20 & 7.09 & 100.00 \\
\hline
\end{tabular}

Sumber data: Tabel Ditribusi Frekuensi Motivasi belajar bahasa Arab 2014

Berdasarkan rekapitulasi motivasi belajar bahasa Arab mahasiswa/responden tersebut maka dapat ditarik kesimpulan bahwa rata-rata tingkat motivasi belajar bahasa Arab responden/mahasiswa berada pada kategori selalu/tinggi yaitu 42,10 persen. Lebih jelasnya dapa dilihat pada diagram di bawah ini.

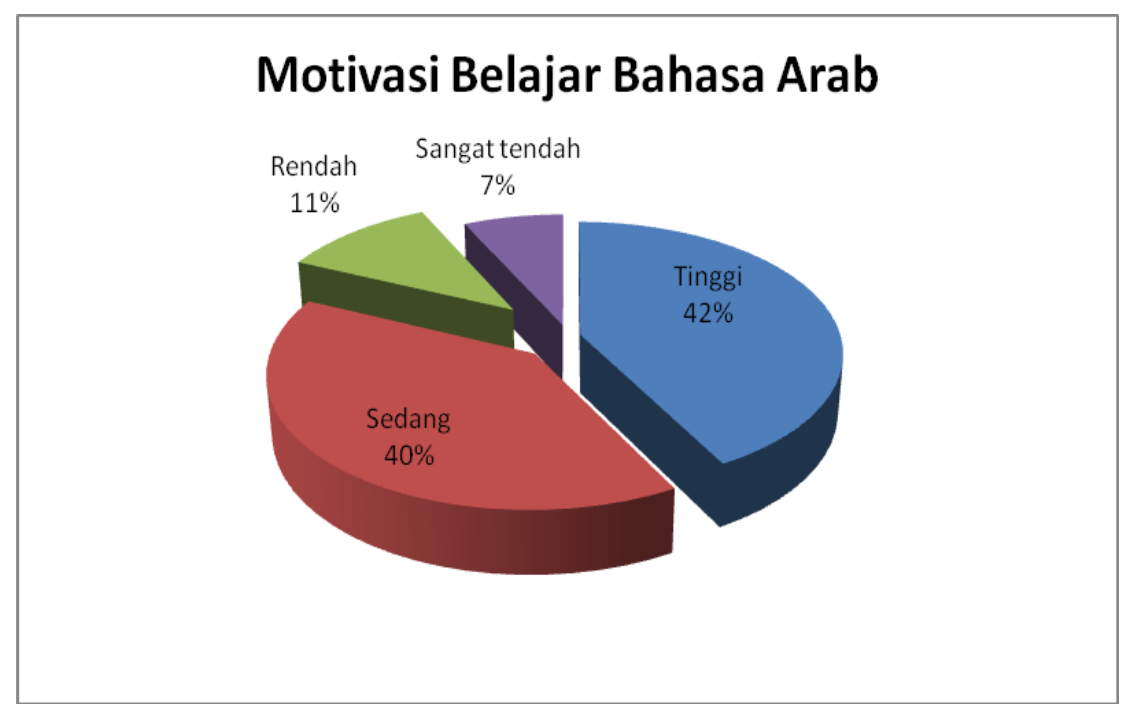

Gambar 3. Motivasi belajar bahasa Arab

\section{Hubungan antara Motivasi dan Hasil Belajar Bahasa Arab}

Berdasarkan hasil analisis data maka diketahui bahwa koefisien korelasi (r) sebesar 0,78 antara variabel $\mathrm{X}$ dan variabel $\mathrm{Y}$. Untuk mengetahui koefisien korelasi hasil perhitungan SPSS tersebut signifikan atau tidak signifikan, perlu dibandingkan $r$ tabel dengan tarap kesalahan 5\% dan $N=45$, ditemukan dalam tabel harga $\mathrm{r}$ 0,294. Ini berarti harga $r$ lebih tinggi daripada harga tabel.

Berdasrkan hal ini, dapat dikatakan bahwa hipotesis penelitian yang diajukan dinyatakan diterima atau hipotesis statistik yaitu $\mathrm{H}_{0}$ ditolak. Dengan dasar ini dapat dikatakan sampel penelitian ini dapat mengenerliasikan keadaan populasi. Untuk megetahui keeratan hubungan antara variabel motivasi dan hasil belajar bahasa Arab, dapat dilihat pada tabel kategori koefisien korelasi 0,60-0,799 dan hasilnya adalah kuat, karena nilai $\mathrm{r}$ sebesar 0.78 berada di antara kategori koefisien korelasi tersebut. Ini berarti hubungan antara motivasi belajar dan hasil belajara bahasa Arab mahasiswa jurusan Pendidikan Bahasa Arab Fakultas Tarbyah dan Keguruan UIN 
Alauddin Makassar adalah kuat.

\section{SIMPULAN}

Berdasarkan hasil analisis data yang telah dikemukan terdahulu, dapat ditarik kesimpulan sebagai berikut:

1. Hasil belajar bahasa Arab mahasiswa jurusan Pendidikan Bahasa Arab pada Fakultas Tarbiyah dan Keguruan UIN Alauddin Makassar pada umumnya ratarata berada pada kategori sedang yakni $31,11 \%$.

2. Motivasi belajar bahasa Arab mahasiswa jurusan Pendidikan Bahasa Arab pada Fakultas Tarbiyah dan Keguruan UIN Alauddin Makassar rata-rata berada pada kategori tinggi yaitu 42,10 persen.

3. Hubungan antara motivasi belajar dan hasil belajar bahasa Arab mahasiswa Jurusan Bahasa Arab adalah kuat karena r hitungnya adalah 0,78.

\section{CATATAN AKHIR}

1. Sumidjo, Kolaborasi dan Pengembangan jejaring Kerja, Jakarta: Lembaga Administrasi RI, 1999, h. 71.

2. Prayitno, Layanan Bimbingan Kelompok dan Konseling Kelompok, Padang: Universitas Negeri Padang, 2004, h. 3.

3. Sugihartono, dkk., Psikologi Pendidikan, Yogyakarta: UNY Press, 2007.

4. Syaiful Bahri Djamarah, Prestasi Belajar dan Kompetensi Guru, Surabaya: Usaha Nasional, 1994, h. 19.

5. Syaiful Bahri Djamarah, Prestasi Belajar dan Kompetensi Guru, h. 21.

6. Slameto, Belajar dan Faktor-Faktor yang Mempengaruhinya, Jakarta: Rineka Cipta, 1995, h. 2.

7. Molyono Abdurahman, Pendidikan bagi Anak yang Berkesulitan Belajar, Cet. III; Jakarta: Renika Cipta, 2003, h. 37.

8. Dimyati dan Mudjiono, Belajar dan Pembelajaran, Jakarta: PT Rineka Cipta, 2009, h. 3

9. Nana Sudjana, Penilaian Hasil Proses Belajar Mengajar, Cet. XV; Bandung: PT. Ramaja Rosdakarya, 2010, h. 22.

10. Wahidmurni, Alifin Mustikawan, dan Ali RidH0, Evaluasi Pembelajaran: Kompetensi dan Praktik, Yogyakarta: Nuha Letera, 2010, h. 18.

11. Nasution, Dikdatik Asas-asas Mengajar, Jakarta: PT. Bumi Aksara, 1995, h. 73.

12. Sugihartono, dkk., Psikologi Pendidikan,

13. Marianto Samosir, Psikologi Pendidikan, Jakarta: PT Indeks, 2011, h. 99.

14. Abraham H. Moslow, Motivasi dan Kepribadian, Bandung: PT Remaja Rosdakarya, 1993,

15. Muhammad Surya, Psikologi Konseling, Bandung: CV. Pustaka Bani Quraisy, 2003, h. 112.

16. Muhammad Surya, Psikologi Konseling, h. 113.

17. Abraham H. Moslow, Motivasi dan Kepribadian, h. 53.

18. Abraham H. Moslow, Motivasi dan Kepribadian, h. 55.

19. Abraham H. Moslow, Motivasi dan Kepribadian, h. 56.

20. Robert E. Slavin, Psikologi Pendidikan (Teori dan Praktik), Jakarta: PT Indeks Permata Puri Media, 2009, h. 109. 
21. Marquis dalam Purwanto (1998)

22. Sardiman, A.M., Interaksi dan Motivasi Belajar Mengajar, Jakarta : C.V. Rajawali, 2007, h. 64.

23. Sardiman, A.M., Interaksi dan Motivasi Belajar Mengajar, h. 85.

24. Oemar Hamalik, Kurikulum dan Pembelajaran. Jakarta: PT. Bumi Aksara, 2008, h. 161.

25. Sugiono, 2007, h. 11.

26. Sugiyono, $1997, \mathrm{~h}$.

\section{DAFTAR PUSTAKA}

Abdullah, Amin. Filsafat Etika Islam: Antara Al-Gazali dan Kant. Cet. II; Bandung: Mizan, 2002.

Abdurrahman, Molyono. Pendidikan Bagi Anak yang Berkesulitan Belajar. Cet.III; Jakarta: Renika Cipta, 2003.

A.M., Sardiman. Interaksi dan Motivasi Belajar Mengajar. Jakarta: PT. Raja Grafindo Persada, 2007.

-----.. Prosedur Penelitian Suatu Pendekatan Praktek. Jakarta : Rineka Cipta, 1996.

Arikunto, Suharsimi. Manajemen Penelitian. Jakarta: Rineka Cipta, 2000.

Depdiknas. Bunga Rampai Keberhasilan Guru dalam Pembelajaran (SMA, SMK, dan SLB). Jakarta: Depdiknas, 2006.

Dimyati \& Mudjiono. Belajar dan Pembelajaran. Jakarta: Proyek Pembinaan dan Peningkatan Mutu Kependidikan, Dirjen Dikti Depdikbud, 1994.

------. Belajar dan Pembelajaran. Jakarta: PT Rineka Cipta, 2009.

Djalal, M.F. Penilaian Dalam Pengajaran Bahasa Asing. Malang: P3T IKIP, 1996.

Malang, Fuad. Dasar-Dasar Pendidikan. Jakarta: Rineka cipta, 2005.

Djamarah, Syaiful Bahri. Prestasi Belajar dan Kompetensi Guru. Surabaya: Usaha Nasional, 1994.

------. Psikologi Belajar. Jakarta: Rineka Cipta, 2002.

Guilford. Pshycological Testing, Allyn Bacon. Inc, 1973.

Hamalik, Oemar. Kurikulum dan Pembelajaran Jakarta: PT. Bumi Aksara, 2008.

Husein, Umar. Metode Penelitian untuk Skripsi dan Tesis Bisnis. Cetakan ke-6. Jakarta: PT RajaGrafindo PersadaIhsan, 2004.

Maslow, Abraham H. Motivasi dan Kepribadian. Bandung: PT Remaja Rosdakarya, 1993.

Nasution. Didaktik Asas-Asas Mengajar. Jakarta: PT Bumiaksara, 1995.

Prayitno. Layanan Bimbingan Kelompok dan Konseling Kelompok. Padang: Universitas Negeri Padang, 2004.

Salvin, Robert E. Psikologi Pendidikan (teori dan praktik), Jakarta: PT Indeks Permata Puri Media, 2009.

Samosir, Marianto. Psikologi Pendidikan. Jakarta: PT Indeks, 2011.

Sardiman, A.M. Interaksi dan Motivasi Belajar Mengajar, Jakarta: PT. Raja Grafindo Persada, 2007.

Slameto. Belajar dan Faktor-Faktor yang Mempengaruhinya. Jakarta: Rineka Cipta, 1995. . Belajar dan Faktor-Faktor yang Mempengaruhinya. Jakarta: Rineka Cipta, 2003. 
Sudjana, Nana. Penilaian Hasil Proses Belajar Mengajar. Cet. XV; Bandung: PT. Ramaja Rosdakarya, 2010.

Sugihartono, dkk. Psikologi Pendidikan. Yogyakarta: UNY Press, 2007.

Sumidjo. Kolaborasi dan Pengembangan jejaring Kerja. Jakarta: Lembaga Administrasi RI, 1999.

Surya, Muhammad. 2003. Psikologi Konseling, Bandung: CV Pustaka Bani Quraisy.

Uno, Hamzah B., dkk. Pengantar Teori Belajar dan Pembelajaran. Cet. II. Gorontalo: Nurul Jannah, 2008.

Usman, Moh Uzer dan Lilis Setiawati. Upaya Optimalisasi Kegiatan Belajar Mengajar. Bandung: Remaja Rosdakarya, 2001.

UU No. 20 Tahun 2003 Tentang Sistem Pendidikan Nasional.

Wahidmurni, Alifin Mustikawan, dan Ali Ridho. Evaluasi Pembelajaran: Kompetensi dan Praktik. Yogyakarta: Nuha Letera, 2010. 